\title{
Writers, Novels and Banyan Trees: Notes on Vikram Seth's A Suitable Boy
}

\author{
José Francisco Fernández Sánchez \\ I.E.S. El Palmeral, Vera (Almería)
}

\begin{abstract}
Vikram Seth's first prose novel A Suitable Boy (1993) has been considered by critics and reviewers as a return to traditional ways of writing, particularly after the eighties, a decade of experimentation in the novel. However, a close reading of the book may reveal connections in the narrative with a contemporaray mood also found in other recent novels. The aim of this article is to show that Seth's work is deeply embedded in the ideological issues of its time, despite Seth's anti-intellectual statements in a conversation with the author which is also recorded here.
\end{abstract}

Since its publication in 1993, Vikram Seth's novel A Suitable Boy has aroused a considerable amount of interest among critics and readers basically for one main reason: the novelty of the product. A Suitable Boy, a novel 1349 pages long, was announced as a traditional novel, both in its themes and in the way it deals with them, and the author himself confessed in interviews that he just wanted to tell a story. The novelty of the product, then, consisted of its "oldness," and the strongly implied assumption in such presentation was that those traditionally long novels in which a good story was told were no longer available. The book was heralded as the return to more traditional ways of writing. At a time when the novel written in English was considered to be in a state of expansion, exploring new possibilities, the novel by Seth was seen as solid ground to stand on in the confusion. 
Reviewers made further emphasis on the fact that being a novel which deals with an important moment in the history of India, the first years after independence, it does not contain any elements of Magic Realism. It is the story of a Hindu family, ordinary people who are struggling in a particular moment of their lives, in this case the search for an appropriate husband for their youngest daughter, without the assistance of spirits, gods, magic or fantasy.

The novel was purposely presented as an alternative to both postmodern playfulness, present in much of the fiction of the 80s, and recourse to Magic Realism, common in some of the novelists of former British colonies. This novel was supposed to be straight,"pure" fiction, and Seth made clear that that was exactly what he meant. Moreover, since the publication of the novel, Seth has displayed an anti-writerly attitude, stating his ignorance of literary theory, and claiming that there is no need for it either. "The kinds of books I like reading most," he said to me during an interview, "modern books or old books, are books which don't make me too conscious about what exactly it is to be a writer. I'm not really interested in writers, I'm interested in the general world, if it includes writers, fine, but I'm not interested in the writer examining his own navel, I mean, I prefer, let me put it this way, Thomas Hardy or Yeats, to someone like Ezra Pound. It's not a question of contempt. I don't have to justify my views, luckily, because I don't teach literature. I can read Montaigne one day and Tintin the next." Seth seems to agree with one of his characters, a teacher of English literature who despises the critical opinions of a young novelist by saying "'He's just a writer, he knows nothing at all about literature""(394)."

As we have said before, Vikram Seth has taken in interviews and reports an antiintellectual stand (and we mean by the use of this expression, in this particular context, a rejection of the aesthetic practices commonly associated with Postmodernism), and a first reading of A Suitable Boy may confirm this: there is no explicit intrusion of the author in the narrative, no authorial voice interrupts the flow of discourse to address the reader and to question the complexities of the task. No mention is made in the book of the constructed quality of the fiction, no overt emphasis is made on the artifice of its telling. As Vikram Seth said during his stay in Spain promoting his novel, he was against writers who became the protagonists of their work. What mattered to him was the telling of the story and the building up of characters. The problem with English literature, he insisted, was that it had been kidnapped by academia. ${ }^{2}$

However, a more careful reading contradicts Seth's claims. Despite his denial of theory there are indeed references in the novel about its own internal disposition. These references take the form of indirect statements about how A Suitable Boy is conceived and structured. Let's consider, for instance, the following paragraph in which one of the characters, the poet Amit, who happens to be in the process of writing a novel himself, considers his work as a sort of organic entity:

'What is it like to write a novel?' asked Lata after a pause. 'Don't you have to forget the "I" or the "one" - ?"

'I don't know exactly,' said Amit. 'This is my first novel, and I'm in the process of finding out. At the moment it feels like a banyan tree.'

'I see,' said Lata, though she didn't. 
'What I mean is,' continued Amit, 'it sprouts, and grows, and spreads, and drops down branches that become trunks or intertwine with other branches. Sometimes branches die. Sometimes the main trunk dies, and the structure is held up by the supporting trunks.'(483)

The banyan tree is a recurrent symbol in the novel, the object of frequent comparisons by characters, the setting of decisive scenes in the story and also a symbol of the new emerging nation, but basically the banyan tree represents clearly the structure of $A$ Suitable Boy. The novel begins with the search for an adequate husband for Lata, the youngest girl of the Mehra family. Her elder sister has just got married and Lata's dominant and sentimental mother sets herself to the task, "You too will marry a boy I choose"'(3). What is supposed to be the main line of the novel becomes a secondary story when the author deals with the rest of the Mehras, or when the reader is acquainted with the Kapoors, the family of Pran, Lata's brother-in-law, and subsequently the circle spreads itself, returning from time to time to Lata's sentimental affairs, but gradually stretching to further points of the family tree, as when Seth describes the eccentric Chatterjis, another family related to the Mehras via Lata's brother, or when, because of Pran's father involvement in politics, the reader is offered a large picture of the corrupted world of Indian politics after independence, with Nehru trying to hold the reins of the Congress Party.

Seth starts from the main trunk of Lata's story and gradually he unveils other supporting trunks that are equally important in the development of the novel, with branches connected between them, and trunks that develop an astounding number of branches. All of them are described by Seth with the same interest and curiosity, the whole tree, as it were, being bathed in the same sap, and details of the life of a servant are depicted with the same freshness as the account of the general elections of 1952, in which some of the characters take part. Sometimes the author pays close attention to an insignificant leaf on a remote branch. In chapter 8.10 , for instance, we are told the story of Kachheru, a servant in the family of the Urdu teacher of Maan, the brother of Lata's brother-in-law, and in that chapter the rest of the characters vanish and it's only Kachheru's story that matters. Later the plot will return to Maan and Lata, but during that sequence it is the humble servant who is the main protagonist of the novel.

There is another reference to the novel's structure when Amit compares his work in progress with a musical piece. This time the model is not a banyan tree, but the idea of interconnectedness is the same:

'I've always felt that the perfomance of a raag resembles a novel - or at least the kind of novel I'm attempting to write. You know,' he continued, extemporizing as he went along, 'first you take one note and explore it for a while, then another to discover its possibilities, then perhaps you get to the dominant, and pause for a bit, and it's only gradually that the phrases begin to form and the tabla joins in with the beat ... and then the more brilliant improvisations and diversions begin, with the main theme returning from time to time, and finally it all speeds up, and the excitement increases to a climax.' (394) 
Brian McHale has pointed out that one of the features of postmodernist writing is the focus it displays on its own structure: "it is precisely by foregrounding the skeleton of layers ... that postmodernist fiction achieves its aesthetic effects and sustains interest, in the process modeling the complex ontological landscape of our experience." 3 What we want to show with the previous excerpts is that Seth is self-conscious about his own process of writing, and thus he is situated, willy-nilly, among the practitioners of the form of fiction he despises. We shall turn to this aspect of his work later. Let's consider now some of Seth's opinions on literary matters and how these themes are reflected in $A$ Suitable Boy.

If the figure of the banyan tree, that organic entity where everything is connected, exemplifies Seth's concept of the novel, his training as an economist is the basis for his refusal to engage with theoretical issues. A simple principle governs his ideas on this matter, a principle expressed by one of his characters in the novel. "'I believe in results,' continued Kuku.'When something works I believe in it"' (486). A similar answer was given by Seth when he was asked what was the limit of the intrusion of the author into the life of the characters: "That question is going to be answered by you after you've finished reading the book. You'll see where I'm omniscient, where I'm semi-omniscient, where I' $m$ ignorant, because that also is a technique a writer can use. I think that whatever works, works; that is the only rule in art. I mean, I have said I don't like this, I don't like that, but in fact I like many of the poems of Eliot, I like many of the poems of Whitman. There really are no rules, what works, works." It is his practical mind which makes any consideration of literary theory redundant for him. Common sense and a feeling of "doing things right" seem to be the theory behind his work. It is the writer's control on his material which gives shape to a novel. "I prefer to leave the characters alone," he confirmed "and yet on the other hand you have to exercise artistic control, otherwise your work becomes completely shapeless. It's a combination of inspiration and to some extent architect planning."

Seth's comments on his novel are direct but somewhat vague, and this ambiguity, together with the publicity campaign of A Suitable Boy has helped to create a misleading image. The brandishing of the book as a traditional, old-fashioned novel, the comparison of Seth with canonical writers of the English tradition, and Seth's own anti-intellectual attitude have tended to form the idea of Vikram Seth as being a "bland" writer, that his novel consisted mainly of a love story and a kind portrayal of the lives of some Hindu families. In fact, the novel is not as naive as one may think after reading reviews of it. In this fresco on the first years of India's independence nothing is left hidden. There are no descriptions of explicit sex, for instance, but all kinds of sexual encounters are found in the novel, as well as abortion, adultery, or sexual abuse.

With respect to social aspects, Seth doesn't avoid mentioning the appalling living conditions of the inhabitants of the slums of Brahmpur, or the misfortune of the members of the lower castes, or the helplessness of the untouchables, although the general attitude is not that of denunciation. I pointed out to him that recent novels like Hanif Kureishi's The Black Album (1995) portray the harassment many Asians suffer in Britain, living in substandard housing, victims of racism. Did he think it was the writer's duty to denounce such situations? "Different writers see their roles differently," he said. "A writer's point 
of view is going to come out in his or her work whether they try to disguise it or not. Of course the effect on the reader might be different. Some readers like books which tell them what to think, others don't like what you tell them and so on. So there are different kinds of books, different styles...."

The recent colonial past of the country is not regarded nostalgically, as many of the characters remember their long years spent in British prisons during the struggle for independence. According to the characters in the novel, the British were thrown out of the country thanks to the suffering of many and the actions of providential men like Nehru. The figure of Gandhi appears in the memory of all with an aura of respect. Seth, nevertheless, doesn't forget the corruption and ruthless fight for power that dominate the political circles of the government, and he gives voice to many characters who shout "'Is this what we threw the British out for?'"(1171). Some of the British that remain in India appear in the book making fun of the habits and customs of the natives, but what is more pathetic is the attitude of the new affluent class of Indians, who have adopted all the manners and comforts of the former English ruling class. One of them is Arun, Lata's brother, who tries to behave like an English lord and is more class conscious than his European employers.

But the main issue that doesn't leave the author unaffected is religious fanaticism. Conflict between Hindus and Muslims is not treated lightly, and the author is precise in the description of how a small incident can cause a riot resulting in death and brutality on both sides. Despite Seth's emphasis on not being included in the narrative, on these occasions he displays something like authorial comment in the form of cold and bitter irony. During a riot in the city of Brahmpur, when a Muslim mob roams around old streets looking for its Hindu countepart, the author reflects on the fate of three Muslim drummers, innocent victims of fear and hatred, who "lay murdered by the wall of the temple, their drums smashed in, their heads half hacked off, their bodies doused in kerosene and set alight - all, doubtless, to the greater glory of God"(1058).

Vikram Seth may belong to that kind of writer who doesn't like to tell their readers what to think, but he definitely makes clear in the novel his position against religious confrontation and intolerance. He describes favourably the actions of responsible Hindu leaders who take steps to prevent Muslim harassment by the Hindu majority, despite Hindu persecution in neighbouring Pakistan. The story of deep friendship between Maan and his Muslim friend Firoz, above religious differences, and in particular the episode in chapter 15.12 when Maan saves Firoz's life in the face of a Hindu mob thirsty for Muslim blood, is an example of how Seth comes out in favour of understanding and common sense above religious fanaticism. The idea of tolerance of all cultures was made explicit when I asked Seth which culture he belonged to. "Take a banyan tree." He answered. "A banyan tree has lots of roots, you can't even tell sometimes what the original trunk is, how do you say 'the trunk is rooted here, or is it rooted there, or is it unrooted?' People think if you can understand more than one kind of culture you must necessarily be some kind of rootless cosmopolitan. I don't think so at all. I think that is true of Spain, to give you an example, some people are rooted in more than one culture - certainly that is true of Granada. And the same applies for people in India: Hindu culture, Muslim culture...." So he didn't consider himself attached to just one culture? "No, Why? One should not feel a stranger 
in one's own country, definitely not, but one should not try to be like a complete stranger in the world as well - the world is too interesting, and a life is only 70 years or 80 years long, why not spend it understanding one's own culture but also trying to understand others?." Understanding and tolerance, then, are the main premises on which his entire work rests. His words on this issue are reminiscent of the final paragraphs in his book of non-fictional prose, From Heaven Lake (1983). In this account on his journeys through China and Tibet Seth laments the lack of contact between two neighbouring countries like China and India, and he expresses again a plea for understanding among different cultures:

But on a personal level, to learn about another great culture is to enrich one's life, to understand one's own country better, to feel more at home in the world, and indirectly to add to that reservoir of individual good will that may, generations from now, temper the cynical use of national power. ${ }^{4}$

In a foreword to a new edition of From Heaven Lake this deeply felt attitude takes the form of a strong denunciation of the violence with which the government of Beijing crushed the peaceful protests for freedom in April 1989. As in the description of the fictitious riots in A Suitable Boy, Seth shows the same indignation when describing the brutal repression of students in Tiananmen Square:

The firing of salvos into crowds, often while they were attempting ineffectually to flee, the crushing to death by tanks of unarmed students, the indiscriminate slaughter of bystanders, in fact the entire operation was marked by a deliberate and sickening viciousness. ${ }^{5}$

In the case of A Suitable Boy Seth's emphasis on tolerance is shown in his attention to the diversity of cultures in the complex map of India's traditions. Hindu culture and Muslim culture are treated equally and respectfully, and at the same time the main characters, who are members of a higher Hindu caste, acknowledge the influence of British culture in their lives. In order to be a prospective husband for Lata, for instance, to speak good English is a powerful asset. When they ask Amit, the poet, why he writes in English and not in Bengali, his mother tongue, he answers that he can express himself better in English. Besides, he adds, "'we are all accidents of history and must do what we are best at without fretting too much about it. Even Sanskrit came to India from outside"'(1253). Excerpts like this one provide a clear picture of what Seth's own thoughts are about the validity of all cultures, as if he were aware that experiment and innovation, as Randall Stevenson points out, have come from writers who have been little resistant to the influence of other traditions:

No author aware of two or more literary traditions can remain unquestioningly content with the conventions of any one of them. Contact with another culture and literature helps create for writers a sense of the character and limitations of their own, encouraging the pursuit of alternatives and possibilities of innovation and change. ${ }^{6}$ 
Seth is definitely in favour of the openess to other traditions that Stevenson speaks about. This receptive attitude has as a consequence in the novel the author's demystifying criticism of India, particularly in the description of Hindu millenary traditions like the festival of the Pul Mela, an event in which pilgrims from all over the country come to bathe in the Ganges. In one of the scenes of the book, because of bad organization and general inefficiency, more than a thousand people die crushed by the crowd or suffocated in the tumult of the processions.

Seth's demystifying attitude is more evident in his account of the privileges and authoritarianism of the Rajas, exemplified in the despotic figure of the Raja of Marh. Such figures find it difficult to accomodate to the new legislation, in particular the passing of the Zamindari Abolition Act, which centers the political debate in the novel. The passing of such bill would mean the withdrawal of massive land extensions from inefficient landlords. Seth's criticism is not blind to obsolete hierarchies and old privileges: "Every few steps a crier announced the Raja's presence, and rose-petals were flung into the air to his greater glory. It was idiotic" (703).

Perhaps only in this sense, Seth might resemble a writer like Salman Rushdie, someone who "finds in many symbols of nationalist cultural assertion a reactionary feudalism reasserting itself within the modern state."

The question that remains unaddressed, and the subject of a more complete study, is Seth's position in post-colonial literature and his relation with other writers from former British colonies. It should be taken into account, however, that Seth is a writer who avoids being classified in one movement, just as he avoids been attached to just one culture. $\mathrm{He}$ is not a writer concerned with stylistic innovation but, as we have already seen, he is not the traditional writer the promotion campaign of the novel has tried to present. After reading A Suitable Boy Margaret Drabble said that it was almost like reading Trollope, but that even in Seth's narrative one could find postmodernist devices. ${ }^{8}$ There aren't in $A$ Suitable Boy those features commonly associated with postmodernist fiction, like a split narrative, a questioning of the author's reliability, a taste for pastiche, a reworking of history or the recourse to fantasy and magic. But it is nevertheless true, and this could well be what Drabble meant, that Seth's attempts to recreate a traditional way of story telling cannot avoid being embedded in the literary mood of the times. The author's selfconsciousness and his emphasis on multi-culturalism are aspects of his work which connect him with the forms of contemporary writing he says he is trying to escape from.

It could be interesting to give an example that illustrates Seth's middle ground position between tradition and modernity. The writers that are favoured by the characters in the novel might give at first sight the idea of a classical taste for literature. Lata's favourite poet is Tennyson; Amit couldn't stop reading Middlemarch and he has devised a comfortable method of reading Shakespeare. But Pran, a lecturer in English at Brahmpur University, fights to include James Joyce in the syllabus of the English Department, a risky choice in the context of $1951 .{ }^{9}$

The singularity of Seth's position is also reflected in his career as a writer. As he proudly repeats in interviews, Seth didn't study English Literature at university. He studied Economics at Oxford and California, and he also lived in China. Prior to A Suitable Boy 
he had published some volumes of poetry and a celebrated novel in verse, The Golden Gate (1986).

Finally, with respect to other aspects of the Seth phenomenon, his characteristic disdain of literary theory and intellectuals in general is probably genuine, but his attitude doesn't affect the contemporary tone of A Suitable Boy. His comments on this matter remind those of John Fowles when he was asked what advice he had for young novelists. "'Anything,"' he said, "'but don't be a teacher'."10

\section{Notes}

1. Seth, Vikram. 1994 (1993). A Suitable Boy. London: Phoenix House. All the page numbers refer to this edition.

2. The promotion of A Suitable Boy in Spain was recorded, among others, by the following newspaper articles:

-Dalrymple, William. "Un Estilo Conservador." Babelia (El País) 29 April 1995: 12-13.

-Fajardo, José Manuel. "Vikram Seth." Magazine El Mundo 27-28 May 1995: 86.

-Gafarot, Xavier. "Los que Escriben Son unos Cotillas." Diario Dieciséis 8 May 1995: 51.

3. McHale, Brian. 1987. Postmodernist Fiction. New York and London: Methuen, p.39.

4. Seth, Vikram. 1993 (1983). From Heaven Lake. London: Phoenix, p. 178.

5. Ibid., Foreword, p. x.

6. Stevenson, Randall.1993. A Reader's Guide to the Twentieth-Century Novel in Britain. Hemel Hempstead: Harvester Wheatsheaf, p. 135.

7. King, Bruce. 1991. "The New Internationalism: Shiva Naipaul, Salman Rushdie, Buchi Echemeta, Timothy Mo and Kazuo Ishiguro." The British and Irish Novel since 1960, ed. James Acheson. New York: St. Martin Press, p. 193.

8. Margaret Drabble. Personal Interview. 2 November 1994.

9. Malcolm Bradbury confirms that many reputations that today are completely established, were not so until the 1940s and 1950s, among them Joyce's. In Possibilities. Essays on the State of the Novel. 1973. London: Oxford University Press, p. 7.

10. Onega, Susana. 1988. "Fowles on Fowles." RCEI 17, p. 247. 